Emilia Szumska - Rafal Jurecki - Marek Pawelczyk*

\title{
ASSESSMENT OF TOTAL COSTS OF OWNERSHIP FOR MIDSIZE PASSENGER CARS WITH CONVENTIONAL AND ALTERNATIVE DRIVE TRAINS
}

The number of alternatively powered vehicles in Poland and EU is growing steadily. Different type of vehicle drive trains determine variations in their performances from economical and environmental technological aspects. The aim of this paper was to investigate the cost efficiency and environmental aspects of midsize passenger cars equipped with different drive train technologies: conventional, hybrid, electric and LPG fueled engine. To this purpose, the Total Cost of Ownership (TCO) method was used. Calculations were carried out by AFLEET Tool. The results show that the LPG fueled car has the lowest TCO, while the cars equipped with electric drivetrain indicate the highest TCO. However the electric car recorded the lowest cost of air pollutant emissions and externalities costs.

Keywords: Total Cost of Ownership (TCO), alternatively powered vehicles, hybrid electric vehicles, air pollutant emission

\section{Introduction}

Alternative fueled vehicles, as well as vehicles with alternative power train, offer the opportunity to reduce greenhouse gases emissions and limit the oil dependency. Air pollution is a big problem in Polish urban areas. For this reason, the Polish government has adopted a new law on electric mobility aimed to promote and disseminate the low-emission vehicles. In 2017 according to [1] a significant growth of registration new electric and hybrid electric passenger cars was observed in Poland. Number of electric cars (including plug-in hybrids) reported growth by $45 \%$ compared to previous year. The number of passenger cars equipped with hybrid electric drive train increased by $40 \%$ in comparison to 2016 . It is worth noting that registrations of cars fitted with a diesel engine increased only by $2.8 \%$ related to the previous year. Figure 1 presents the share of propulsion type in registrations of new passenger cars in 2017.

In 2017, the largest share of the new registered passenger cars in Poland had the gasoline fueled vehicles, while in EU over a half of the new cars were equipped with diesel engine. In EU new registered cars fitted with electric and hybrid had higher share than in Poland. The reverse situation is in the case of natural gas fueled vehicles [1-2]. Various types of vehicle drive train demonstrate differences in their performances from economical, environmental and technological aspects [3-4]. Alternatively fueled or powered cars ensure lower emission compared to conventional vehicles. Hybrid and electric cars have higher manufacturing costs than the conventional vehicles, which results in higher acquisition price. However, the EVs and hybrids may provide low running costs. The Total Cost of Ownership (TCO) is a useful method to evaluate the costs related to the purchase and use of a car. The TCO may be applied for identification of the most economical type of a vehicle.

The aim of the paper is to evaluate the Total Cost of Ownership for six types of passenger cars: gasoline, diesel, hybrid electric, plug-in hybrid electric, electric and LPG fueled. In this study, the AFLEET Tool was used for the TCO calculation. The presented analysis includes the cost of externalities. Results presented in the paper could be useful in decision making on the purchase of an alternatively powered car.

\section{Total Cost of Ownership (TCO)}

The Total Cost of Ownership (TCO) includes the initial purchase price of vehicle as well as all direct and indirect expenses incurred at its operation, such as repairs, insurance and fuel. The TCO method provides all the costs arising during the acquisition, operation and decommissioning. According to authors of paper [5], the TCO analysis can be conducted in two categories: consumer oriented studies and the society oriented studies. In the first group, the costs distinguished by the consumers are incorporated and the different vehicle technologies are compared. In the case of the society oriented TCO studies, the consumer costs are extended to externalities, such as air pollutant, noise, accidents, congestions, climate change and environmental impacts.

Various studies have been conducted recently using the TCO method to analyze the costs effectiveness of the different vehicle technologies. For instance, the papers [6-8] present the TCO analysis for conventional, hybrid and electric cars. Studies [9-11] show the Total Cost of Ownership calculations for urban buses equipped with different types of propulsion drive. Research [12] delivers the TCO calculation conducted for plug-in hybrid electric vehicles for medium-duty truck.

Paper [5] provides the TCO analysis conducted for conventional, electric and hybrid electric passenger cars concerning three different car segments. Results show that the investigated electric vehicles from medium and small cars segment are less cost efficient then gasoline or diesel powered

\footnotetext{
* Emilia Szumska, Rafal Jurecki, Marek Pawelczyk

Kielce University of Technology, Poland

E-mail: eszumska@tu.kielce.pl
} 

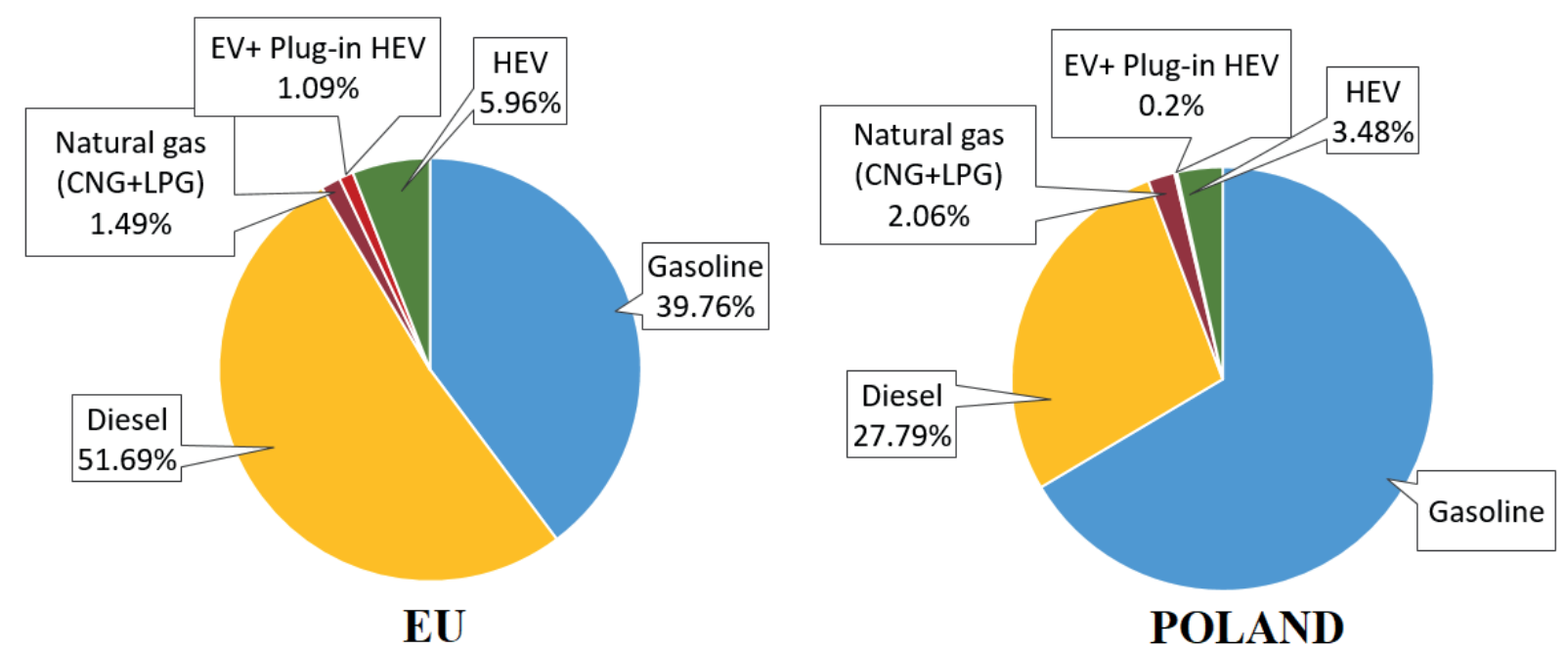

Figure 1 Share of drive train type in registrations of new passenger cars in 2017 [1-2]

cars. The difference in the TCO with conventional and electric vehicles is lower compared to the premium city car segment.

Numerous studies the Total Cost of Ownership calculation contain the environmental and/or social impacts of vehicles. Studies [13-14] present the Total Cost of Ownership including the emission cost, associated with air pollution, either greenhouse gases $\left(\mathrm{CO}_{2}, \mathrm{NO}_{2}, \mathrm{CH}_{4}\right)$ or local air pollutants $\left(\mathrm{NO}_{x}, \mathrm{SO}_{x}, \mathrm{PM}_{\mathrm{x}}\right)$,. The TCO method was used to evaluate and compare the cost efficiency of vehicles with the different type of drive train. Research paper [15] presented the Total Cost of Ownership model for alternative vehicle technologies. The TCO was extended with external costs related to vehicle ownership and use. Authors interpreted the individual ownership to a societal perspective by describing the effect of the technologies on the costs for the society ("Total Cost for Society"). The results presented in the paper submit that battery electric vehicles, plug-in hybrid electric vehicles and hybrid electric vehicles have a lower societal cost than petrol, diesel and compressed natural gas vehicles.

The TCO method may be applied to evaluate the cost effectiveness of autonomous vehicles. The results of the research [16] show that the Total Cost of Ownership method can be used to compare fully automated vehicles with non-automated vehicles for personal cars, taxis and trucks. The presented TCO analysis included the costs of time spending for driving. The results show that highly automated vehicles would be attractive and beneficial to the high income groups as the time use related benefits can still be realized in the long-distance travel, but may not be attractive for taxi or mobility service operations, which primarily operate in an urban environment.

There are numerous studies on utilization of the TCO method to evaluate the perspectives of alternatively fueled and powered vehicles in automotive market of a specific region or country. For example, paper [17] provides analysis of the Total Cost of Ownership, social lifecycle cost and energy consumption obtained done for 66 cars with different types of powertrain available in Italy in 2013. The results show that the conventional cars (gasoline, diesel) have the lowest TCO. The electric vehicles indicate the lowest social lifecycle costs. Authors point out that alternative vehicles are still too expensive for consumers.
Study [18] presents the Total Cost of Ownership analysis of electric passenger vehicles in Germany. Results provided in this paper show that hybrid electric vehicles are already promising option from the economical point of view. Authors state that electric vehicles are currently not economically realizable in Germany without governmental subsidies. Similar conclusions were delivered in paper [19]. The contribution presents extensive Total Cost of Ownership analysis of conventional, hybrid and electric vehicles in three countries - the UK, Japan and USA (California and Texas) over a time period of 16 years. The authors indicate that the long term government support enables increasing the interest in hybrid and electric vehicles and growing the number of low-emission vehicles. Paper [20] and studies reffered above show how crucial the government subsidies are for development of electric mobility.

\section{Assumptions for the TCO analysis}

The TCO model includes costs of: acquisition, fuel, maintenance and repair, insurance and license and externalities. It should be noted that some of mentioned cost are relatively variable over the vehicle operational time. The Total Cost of Ownership analysis was conducted for midsize passenger cars equipped with different types of drive systems: conventional with gasoline powered engine (gasoline), conventional with diesel powered engine, hybrid electric with gasoline combustion engine (HEV), plug-in hybrid electric (PHEV), battery electric (EV), and with engine powered by liquid propane gas (LPG). Detailed parameters of investigated vehicles are presented in Table 1. Values of average fuel consumption have been taken from summary [21]. It has been assumed that all the cars operate in an urban driving conditions. The service life of the analyzed passenger cars is 15 years. The annual millage amounts to $20000 \mathrm{~km}$.

The fuel price on global fuel market is hard to predict. Estimate of the stable fuel price during the vehicle operation time is impossible to obtain. In this study, calculations were conducted with assumption that the costs of gasoline is $1.09 \mathrm{EUR} / \mathrm{dm}^{3}$ (4.69 PLN $/ \mathrm{dm}^{3}$ ), costs of diesel: $1.15 \mathrm{EUR} / \mathrm{dm}^{3}\left(4.97 \mathrm{PLN} / \mathrm{dm}^{3}\right)$, costs 
Table 1 Characteristics of analyzed passenger cars [21-25]

\begin{tabular}{|c|c|c|c|c|}
\hline & $\begin{array}{l}\text { Average fuel } \\
\text { consumption }\end{array}$ & $\begin{array}{l}\text { Cost of acquisition } \\
\text { [EUR] }\end{array}$ & $\begin{array}{l}\text { Annual insurance } \\
\text { costs [EUR] }\end{array}$ & $\begin{array}{c}\text { Annual cost of repairs and } \\
\text { maintenance [EUR] }\end{array}$ \\
\hline Gasoline & $6.7\left[\mathrm{dm}^{3} / 100 \mathrm{~km}\right]$ & 11600 & 320 & 580 \\
\hline Diesel & $5.8\left[\mathrm{dm}^{3} / 100 \mathrm{~km}\right]$ & 13000 & 320 & 580 \\
\hline Gasoline Hybrid Electric Vehicle (HEV) & $4.5\left[\mathrm{dm}^{3} / 100 \mathrm{~km}\right]$ & 32500 & 350 & 930 \\
\hline $\begin{array}{c}\text { Gasoline Plug-in Hybrid Electric Vehicle } \\
\text { (PHEV) }\end{array}$ & $1.8\left[\mathrm{dm}^{3} / 100 \mathrm{~km}\right]$ & 35000 & 350 & 930 \\
\hline Electric Vehicle (EV) & $10.8[\mathrm{kWh} / 100 \mathrm{~km}]$ & 35000 & 480 & 980 \\
\hline Liquid Propane Gas (LPG) & $11.6\left[\mathrm{dm}^{3} / 100 \mathrm{~km}\right]$ & 12500 & 320 & 600 \\
\hline
\end{tabular}

of LPG: $0.52 \mathrm{EUR} / \mathrm{dm}^{3}\left(2.25 \mathrm{PLN} / \mathrm{Nm}^{3}\right)$ and the costs of electric energy is $0.44 \mathrm{EUR} / \mathrm{kWh}(1.90 \mathrm{PLN} / \mathrm{kWh})[22-23]$.

The insurance costs depend on a number of different factors, such as age, sex, marital status, and location. Polish insurance companies make the insurance rates also dependent on the type of the drive propulsion. According to [24] the electric vehicles are more expensive to insure than conventional cars.

The repair and maintenance costs include costs of periodic inspections, costs of tires, operating fluids, parts and components replacing, and costs of necessary repairs. The cost of maintenance and repair differ between various drive types. The repair costs of electric and hybrid electric vehicles are higher than for the conventional cars. Some components of electric drive, like the lithium-ion batteries, are very expensive to repair if damaged. An additional reason is the availability of qualified staff to handle work on electric and hybrid cars. The level of repair and maintenance cost of analyzed cars have been provided from study [25]. In the presented TCO model the repair costs of electric and hybrid electric vehicles and the battery replacement costs are included.

The external costs have been calculated by use of the AFLEET Tool. In the TCO analysis described in the paper the externalities include costs of air pollutant emissions (Carbon Monoxide, Nitrogen Oxides, Sulfur Dioxide, Particular Matter: $\mathrm{PM}_{2.5}$ and $\mathrm{PM}_{10}$, Volatile Organic Compounds), costs of greenhouse gases emission, costs of noise, costs of accidents, costs of congestions, and costs of environmental degradation.

The TCO analysis was carried out using the AFLEET Tool, developed by the Argonne National Laboratory (ANL). The AFLEET Tool allows to estimate the lifetime fuel consumption and air pollutant emissions and costs of ownership for the light and heavy duty vehicles. The following drive system options have been taken into account:

- conventional: gasoline, diesel;

- hybrid: gasoline HEV, diesel HEV, diesel hydraulic hybrid, plug-in hybrid;

- electric: EV, EREV (Extended Range Electric Vehicle);

- alternative fuel: biodiesel, ethanol, hydrogen, LPG, CNG, LNG.

The vehicle types in the AFLEET Tool are based on the EPA's Motor Vehicle Emission Simulator (MOVES) as this allows the tool to estimate vehicle operation (e.g. tailpipe, brake and tire wear) emissions for various types of vehicle drives [26]. The user can modify the vehicle purchase price, fuel economy values, annual mileage, fuel and energy price, planned years of ownership, as well as the loan interest rate and term when purchase is financed by a loan.

The AFLEET tool includes the Simple Payback Calculator, Total Cost of Ownership Calculators, Fleet Footprint Calculator and Idle Reduction Calculator. The Simple Payback Calculator analyzes the acquisition and annual operating costs to evaluate a vehicle simple payback for purchasing, average annual petroleum use, greenhouse gases emissions and air pollutant emissions. The Total Cost of Ownership Calculator evaluates the net present value of operating and fixed costs over the operation time of a vehicle, lifetime fuel use, greenhouse gases emissions and air pollutant emissions. The Fleet Footprint Calculator estimates the annual petroleum use, greenhouse gases emissions and air pollutant emissions of investigated vehicle, taking into consideration that older vehicles typically have higher air pollutant emission rates than the newer ones. Finally, the Idle Reduction Calculator analyzes acquisition and annual operating costs to calculate a simple payback of a vehicle acquisition, average annual fuel use, greenhouse gases emissions and air pollutant emissions [26].

The AFLEET Tool displays simulation results in the outputs tables and graphs involving the Total Cost of Ownership and its components, fuel consumption, greenhouse gases emissions, and air pollutant emissions over the planned operation time.

\section{Results}

The Total Cost of Ownership values, estimated for the above mentioned vehicles are presented in Figure 2. The results of provided analysis show that the lowest TCO value has the car equipped with engine fueled by the LPG.

The LPG fueled car indicates $5 \%$ lower TCO compared to diesel vehicle. The Total Cost of Ownership values, reported for the conventional cars, are quite similar. The gasoline powered vehicle has 3\% higher TCO than the diesel one. Car fitted with electric drive has the highest TCO level of the investigated passenger cars. The EV demonstrates $40 \%$ greater TCO in comparison to diesel fueled car. Hybrid cars show higher Total Costs of Ownership than conventional cars. Compared to diesel vehicle, the TCO values are bigger for plug-in hybrid - $40 \%$, for HEV - $36 \%$.

The running costs are referred to as the sum of the fuel costs, maintenance and repairs costs, and insurance costs. Significant differences of running costs of the analyzed vehicles were observed. In comparison to the diesel car, the LPG shows 5\% 


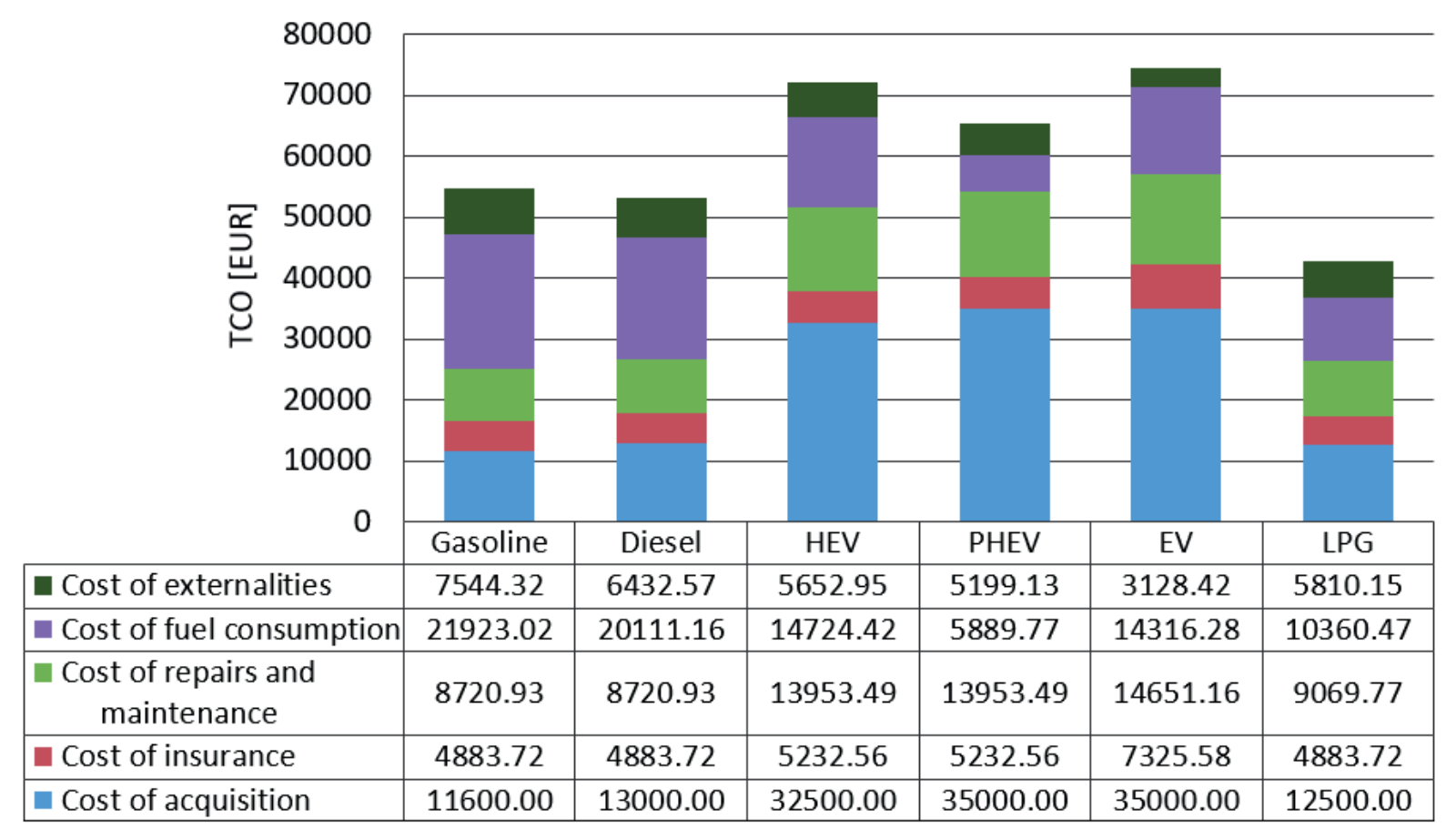

Figure 2 Total Cost of Ownership summary graph
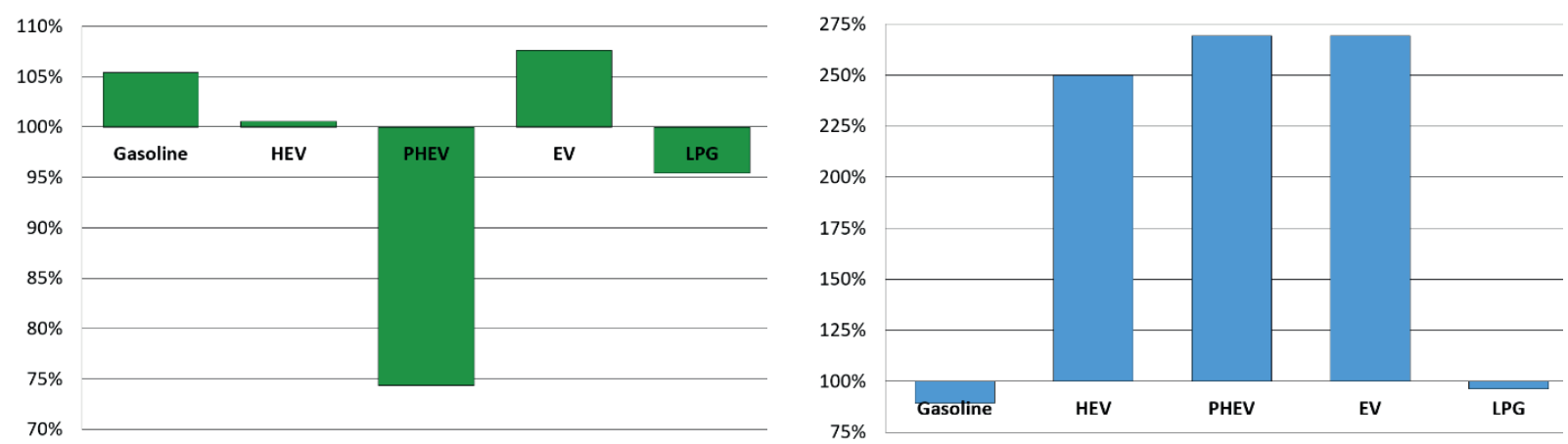

Figure 3 Percentage difference of the running costs (left) and acquisition costs (right) compare to diesel fueled car (100\%)

lower running costs (Figure 3). The main and generally known reason is a lower price of liquefied petroleum gas compared to diesel and petrol.

The plug-in hybrid has the $26 \%$ lower running costs in comparison to diesel fueled car. The PHEV indicates the lowest costs of fuel consumption of the investigated passenger cars. Expenditures incurred on fuel represent approximately $9 \%$ of its TCO. The low values of fuel cost and the running costs could make the PHEV more competitive in the future. The plug-in hybrids are fitted with a large battery that can be recharged by plugging into an electrical outlet. It allows to obtain the fuel savings as using only electric drive until the battery pack is depleted. The conventional cars have the highest operating costs. This is due to high fuel consumption costs, which constitute the biggest share in their TCO. Compared to the diesel fueled car, the operational costs are respectively higher for gasoline - 5\%, for HEV - $1 \%$, for EV - $8 \%$.

The largest part in the TCO of electric and hybrid vehicles represent the costs of acquisition. The purchase price is often the determining factor in purchasing a car. Another issue that can have a serious influence on acquisition decision is limited battery lifetime and the costs associated with its replacement. The purchase costs of EV and HEV constitute almost $47 \%$ of their TCO, while for the PHEV - 54\%. Compared to the diesel fueled car, the costs of acquisition are higher for hybrid - 150\%, for plug-in hybrid and electric - 169\% (Figure 3).

The external costs provided in this analysis include the costs of air pollutant emission, cost of greenhouse gases emission, costs of noise, costs of accidents, costs of congestions, and costs of environmental degradation. The conventional cars indicate the highest externalities costs of the investigated passenger vehicles. The share of external costs in gasoline and diesel TCO value amounts to $14 \%$ and $12 \%$ respectively. The externalities in the PHEV and HEV constitute $8 \%$ of their Total Cost of Ownership. The electric vehicle shows a $51 \%$ lower costs externalities compared to diesel fueled car. Summary of air pollutant emissions during the operating time of investigated vehicles is shown in Figure 4.

The results show that the electric vehicle has the lowest emissions of harmful substances to air. The $\mathrm{CO}$ emission level for an $\mathrm{EV}$ is $52 \%$ lower compared to a diesel fueled vehicle. The LPG fueled car has the lowest particular matter emissions of 


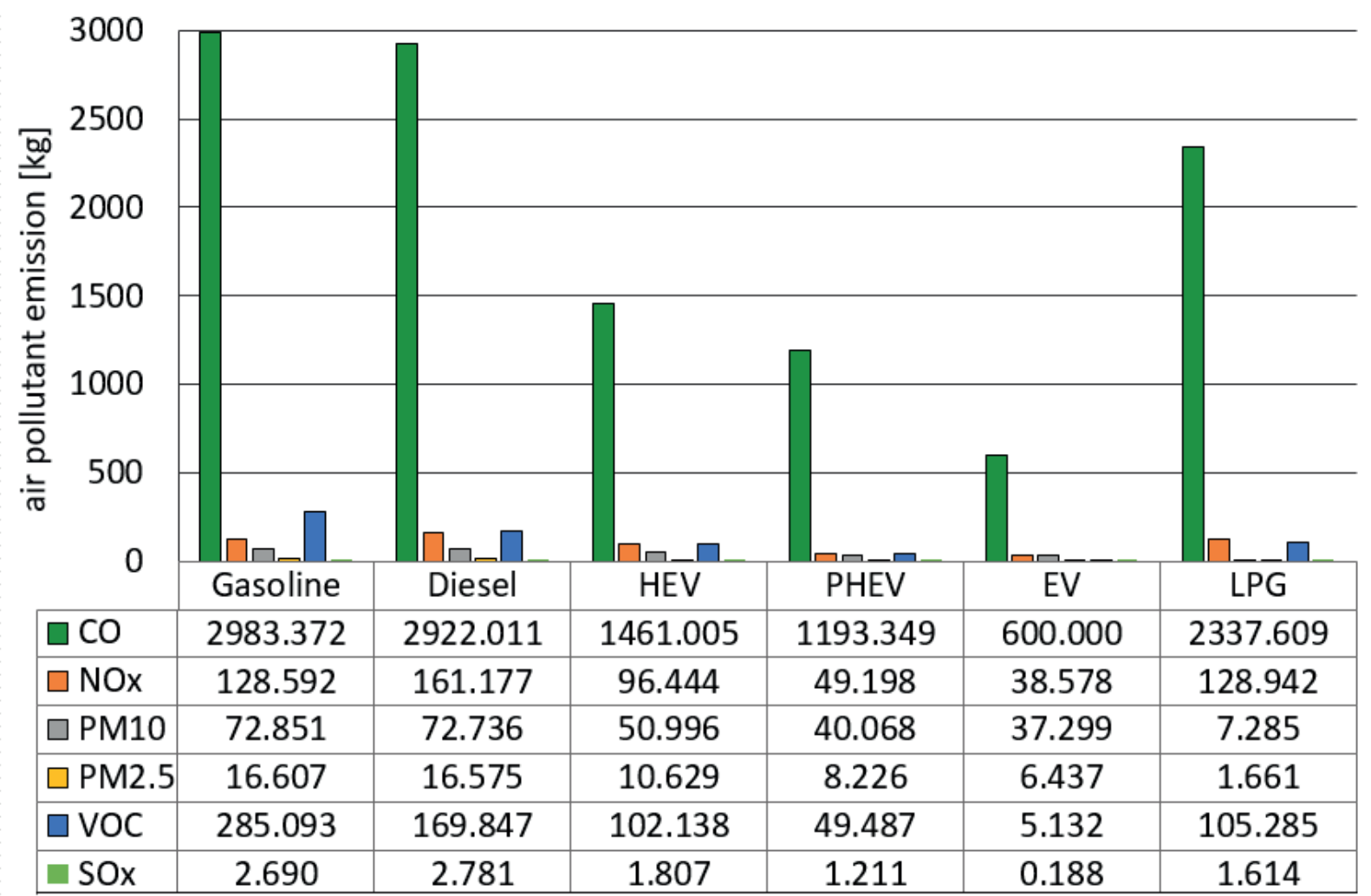

Figure 4 Air pollutant emissions over the operating time of vehicle

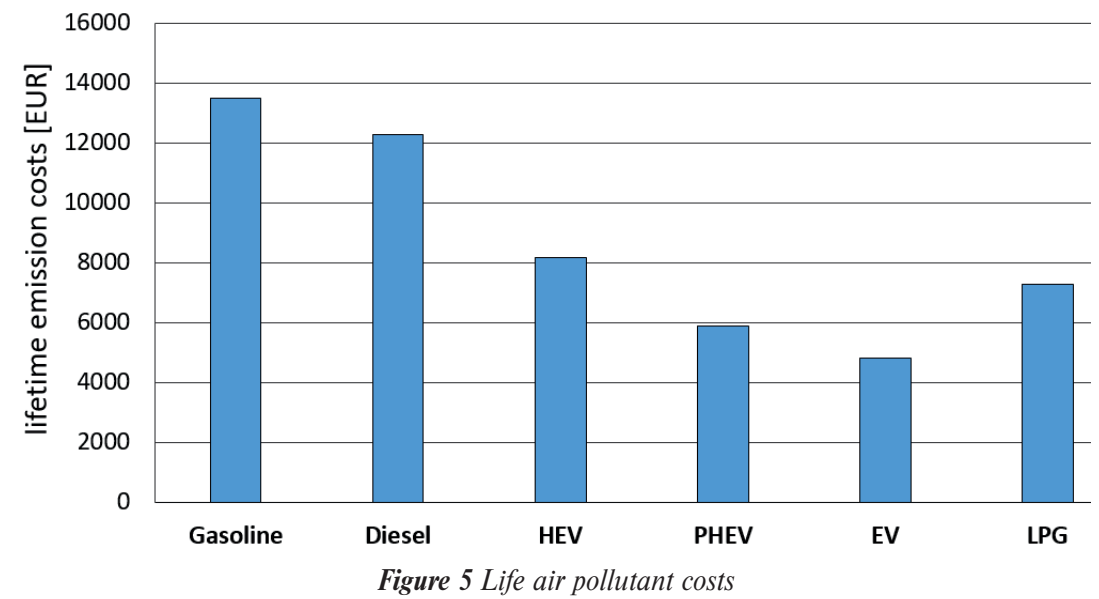

the investigated passenger vehicles. The cars fitted with hybrid electric drive can significantly reduce the $\mathrm{NO}_{\mathrm{x}}$ emission. Nitrogen Oxides emission is respectively lower for the HEV - $40 \%$ and PHEV - 70\% compared to diesel powered vehicle.

Figure 5 presents a comparison of costs associated with the lifetime air pollutant emission estimated by the investigated passenger cars.

Application of alternative powered or fueled drives can reduce the air pollutant costs significantly. The lowest lifetime air pollutant costs indicates the electric car. The EV has the $61 \%$ lower air pollutant costs than the diesel powered car. The gasoline fueled car shows the highest costs of air pollutant emissions of the investigated passenger vehicles. The gasoline car has $10 \%$ higher emission costs as compared to the diesel powered vehicle.

\section{Conclusion}

The presented analysis details the Total Cost of Ownership associated with the type of drivetrain. Provided comparison includes externalities costs. It was found that the LPG fueled car has the lowest TCO and indicates low air pollutant emission. Fuel consumption for the LPG is bigger than gasoline or diesel, but it is compensated by significantly lower price. The LPG fueled cars could be an alternative to replace the conventional cars. Hybrid electric drives train powering the vehicles have the potential to reduce the running costs and amount of environmental impact. Especially the plug-in hybrids can bring cost-savings for the long term use. However, their Total Cost of Ownership is significantly greater than for the conventional cars. 
The results provided in this paper and in the studies presented earlier demonstrate that the hybrid and electric vehicles are still more expensive than the conventional cars. The disadvantages of the HEVs and EVs are high purchase costs and additional costs of battery replacement. The EVs and plug-in hybrids have limited range, thus causing the long-distance journeys much less convenient than gasoline, diesel or hybrid cars. It is promising that prices of the Lithium-Ion batteries are decreasing, while the gasoline and diesel prices are steadily increasing over time. The number of charging station and charging points vary significantly across the EU countries. The Norway has the highest number of installed charging points in Europe. Western EU countries, such as Germany, The Netherlands, France and the UK, already have more than 10,000 public charging points in place. In the Eastern Europe countries the electro mobility is significantly less developed. In Poland in 2018 were 150 charging station located mainly in large urban areas [27]. The European Commission focuses on reducing dependency on oil and oil-related products and foresees the use of common technical specifications for recharging and refueling stations. The EU regulatory requires Member States to develop national policy frameworks for the market development of alternative fuels and their infrastructure. For this purpose, EU elaborated funding programs to support and build a network of high power charging stations infrastructure along major routes across Europe.

\section{References}

[1] PZPM Automotive Industry Report 2018/2019 - Polish Automotive Industry Association [online]. Available from: http://www. pzpm.org.pl

[2] European Vehicle Market Statistic Pocketbook 2017/18, ICCT - International Council on Clean Transportation [online]. Available from: www.theicct.org

[3] CONRADIE, P. D. F., ASEKUN, O. O., SKRUCANY, T., KENDRA, M., STOPKA, O. The effect of fuel on the energy consumption and production of greenhouse gases in transport. The Archives of Automotive Engineering - Archiwum Motoryzacji [online]. 2018, 82(4), p. 5-14. eISSN 1234-754X. Available from: https://doi.org/10.14669/AM.VOL82.ART1

[4] SARKAN, B., STOPKA, O., CHOVANCOVA, M., RYBICKA, I., KAPUSTINA, L. M. Research of individual factors affecting the engine power while a passenger car operation. The Archives of Automotive Engineering - Archiwum Motoryzacji [online]. 2018, 82(4), p. 143-152. eISSN 1234-754X. Available from: https://doi.org/10.14669/AM.VOL82.ART11

[5] LEBEAU K., LEBEAU P., MACHARIS C., VAN MIERLO J. How expensive are electric vehicles? A total cost of ownership analysis. World Electric Vehicle Journal [online]. 2016, 6, p. 996-1007. ISSN 2032-6653. Available from: https://doi.org/10.3390/wevj6040996

[6] HAGMAN J., RITZEN S., JANHAGER STIER J., SUSILO Y. Total cost of ownership and its potential implications for battery electric vehicle diffusion. Research in Transportation Business and Management [online]. 2016, 18, p. 11-17. ISSN 2210-5395. Available from: https://doi.org/10.1016/j.rtbm.2016.01.003

[7] DUMORTIER J., SIDDIKI S., CARLEY S., CISNEY J., KRAUSE R. M., LANE B. W., RUPP J. A., GRAHAM J. D. Effects of providing total cost of ownership information on consumers' intent to purchase a hybrid or plug-in electric vehicle. Transportation Research Part A: Policy and Practice [online]. 2015, 72(A), p. 71-86. ISSN 0965-8564, eISSN 1879-2375. Available from: https://doi.org/10.1016/j.tra.2014.12.005

[8] ZIROGIANNIS N., DUNCAN D., CARLEY S., SIDDIKI S., GRAHAM J. D. The effect of CAFE standards on vehicle sales projections: A total cost of ownership approach. Transport Policy [online]. 2019, 75, p. 70-87. ISSN 0967-070X, eISSN 1879-310X. Available from: https://doi.org/10.1016/j.tranpol.2019.01.006

[9] SZUMSKA, E., PAWELCZYK, M. TCO comparison for city buses equipped with hybrid and conventional propulsion drive / Porownanie TCO autobusow miejskich z hybrydowym i konwencjonalnym ukladem napędowym (in Polish). Prace Naukowe Politechniki Warszawskiej, seria Transport. 2017, 118, p. 277-285. ISSN 1230-9265. Available from: https://www.wt.pw.edu.pl/ $\sim$ ast/ index.php/Badania-i-nauka/Prace-Naukowe-Politechniki-Warszawskiej-Transport/Zeszyty/Zeszyt-118

[10] NURHADI, L., BOREN, S., NY, H. A sensitivity of total ownership for electric public bus transport systems in Swedish medium sized cities. Transportation Research Procedia [online]. 2014, 2, p. 818-827. ISSN 2352-1465. Available from: https://doi.org/10.1016/j.trpro.2014.10.058

[11] GOEHLiCH, D., SPANGENBERG, F., KUNITH, A. Stochastic total cost of ownership forecasting for innovative urban transport systems. IEEE International Conference on Industrial Engineering and Engineering Management : proceedings. 2013. ISBN 978-1-4799-0986-5, p. 1-5.

[12] VORA A. P., JIN X., HOSHING V., SAHA T., SHAVER G., VARIGONDA S., WASYNCZUK O., TYNER W. E. Design-space exploration of series plug-in hybrid electric vehicles for medium-duty truck applications in a total cost-of-ownership framework. Applied Energy [online]. 2017, 202, p. 662-672. ISSN 0306-2619. Available from: https://doi.org/10.1016/j.apenergy.2017.05.090

[13] Mitropoulos, L. K., PREVEdouros, P. D., KOPEliAS, P. Total cost of ownership and externalities of conventional, hybrid and electric vehicle. Transportation Research Procedia [online]. 2017, 24, p. 267-274. ISSN 2352-1465. Available from: https://doi.org/10.1016/j.trpro.2017.05.117 
[14] BISHOP, J. D., MARTIN, N. P., BOIES, A. M. Cost-effectiveness of alternative powertrains for reduced energy use and $\mathrm{CO} 2$ emissions in passenger vehicles. Applied Energy [online]. 2014, 124, p. 44-61. ISSN 0306-2619. Available from: https://doi.org/10.1016/j.apenergy.2014.02.019

[15] DE CLERCK Q., VAN LIER T., LEBEAU P., MESSAGIE M., VANHAVERBEKE L., MACHARIS C., VAN MIERLO J. How total is a total cost of ownership. World Electric Vehicle Journal [online]. 2016, 8(4), p. 736-747. ISSN 2032-6653. Available from: https://doi.org/ 10.3390/wevj8040742

[16] WADUD, Z. Fully automated vehicles: A cost of ownership analysis to inform early adoption. Transportation Research Part A: Policy and Practice [online]. 2017, 101, p. 163-176. ISSN 0965-8564, eISSN 1879-2375. Available from: https://doi.org/10.1016/j.tra.2017.05.005

[17] RUSICH, A., DANIELIS, R. Total cost of ownership, social lifecycle cost and energy consumption of various automotive technologies in Italy. Research in Transportation Economics [online]. 2015, 50, p. 3-16. ISSN 0739-8859. Available from: https://doi.org/10.1016/j.retrec.2015.06.002

[18] BUBECK, S., TOMASCHEK, J., FAHL U. Perspectives of electric mobility: Total cost of ownership of electric vehicles in Germany. Transport Policy [online]. 2016, 50, p. 63-77. ISSN 0967-070X, eISSN 1879-310X. Available from: https://doi.org/10.1016/j.tranpol.2016.05.012

[19] PALMERA K., TATEB J. E., WADUDC Z., NELLTHORP J. Total cost of ownership and market share for hybrid and electric vehicles in the UK, US and Japan. Applied Energy [online]. 2018, 209, p. 108-119. ISSN 0306-2619. Available from: https://doi.org/10.1016/j.apenergy.2017.10.089

[20] POLIAK, M., SEMANOVA, S., MRNIKOVA, M., KOMACKOVA, L., SIMURKOVA, P., POLIAKOVA, A., HERNANDES, S. Financing public transport services from public funds. Transport Problems [online]. 2017, 12(4), p. 61-72. ISSN 1896-0596. Available from: http://transportproblems.polsl.pl/pl/Archiwum/2017/zeszyt4/2017t12z4_06.pdf

[21] The fuel economy of vehicles - AutoCentrum.pl S.A. [online]. [Viewed 2019-02-06]. Available from: https://www.autocentrum.pl/ spalanie

[22] Fuel price in Poland - Information Market S.A. [online]. [Viewed 2019-02-06]. Available from: www.e-petrol.pl

[23] The cost of electricity to charge an electric vehicle - Globenergia Sp. z o.o. [online]. [Viewed 2019-02-06]. Available from: globenergia.pl/miesieczne-koszty-ladowania-auta-elektrycznego

[24] Electric or hybrid car - How much does its insurance cost? - Ubea Sp. z o.o. [online]. [Viewed 2019-02-06]. Available from: https://ubea.pl/Elektryk-lub-hybryda-ile-kosztuje-ich-ubezpieczenie\%2Cartykul\%2C1349

[25] LEWICKI, W. The case study of the impact of the costs of operational repairs of cars on the development of electromobility in Poland. The Archives of Automotive Engineering - Archiwum Motoryzacji [online]. 2017, 78(4), p. 107-116. eISSN 1234-754X. Available from: http://dx.doi.org/10.14669/AM.VOL78.ART8

[26] BURNHAM, A. User guide for AFLEET Tool 2018. Lemont, IL: Argonne National Laboratory, 2018.

[27] SPOTTLE, M., JORLING, K., SCHIMMEL, M., STAATS, M., GRIZZEL L., JERRAM, L., DRIER, W., GARTNER, J. Research for TRAN Committee - Charging infrastructure for electric road vehicles [online]. Brussels: Policy Department for Structural and Cohesion Policies, 2018. ISBN 978-92-846-2854-4, eISBN 978-92-846-2855-1. Available from: https://doi.org/10.2861/013597 